\title{
УЗГОДЖЕНЕ РЕГУЛЮВАННЯ КООРДИНАТ ДВИГУНА-ГЕНЕРАТОРА В РЕЖИМІ ЕЛЕКТРИЧНОГО ГАЛЬМУВАННЯ
}

В.І. Теряєв ${ }^{1}$, канд. техн. наук, доцент, С.О. Бур'ян ${ }^{1}$, канд. техн. наук, доцент, В.П. Стяжкін ${ }^{2}$, канд. техн. наук, ст. наук. співр.

${ }^{1}$ Національний технічний університет України «Київський політехнічний інститут ім. Ігоря Сікорського»,

03056, пр-т. Перемоги 37, м. Київ, Україна.

${ }^{2}$ Інститут електродинаміки НАН України,

03057, пр-т. Перемоги 56, м. Київ, Україна.

Існує ряд установок і технологічних прочесів, рух в яких здійснюється за рахунок зовнішнього джерела енергії, а електрична машина, не будучи основним джерелом руху, постійно або періодично перебуває в режимі генераторного електричного гальмування для забезпечення потрібних характеристики робочого процесу.

Завдання даного дослідження полягає в розширенні функціональних можливостей генератора $i$ двигуна в режимі електричного гальмування. Поставлена задача вирішується за рахунок регулювання координат електричної машини в генераторному режимі. Особливістю запропонованого способу управління є те, щчо одна або кілька координат генератора або двигуна в режимі електричного гальмування примусово задаються зовнішнім джерелом енергії, а метою узгодженого регулювання інших координат електричної машини є забезпечення заданого закону перетворення механічної енергії в електричну або алгоритму руху виконавчого органу робочої машини.

У статті наведено приклад синтезу алгоритму управління регульованим електроприводом на основі принципу узгодженого регулювання координат.

У прикладі розглядається обернений режим роботи насосної установки гідроакумулюючої електростанції. За критерієм незмінності потужності генерації в умовах зміни рівня рідини синтезований алгоритм частотного управління асинхронної машиною, який реалізується шляхом регулювання розрахункової швидкості холостого ходу двигуна, ротор якого обертається зовнішнім джерелом руху зі швидкістю, яка в загальному випадку може змінюватися за довільним законом. Завданням алгоритму управління є підтримка постійної потужності генерачії енергії, незалежно від фактичної швидкості обертання ротора.

Поєднання функцій генератора і електродвигуна в єдиному функиіональному комплексі забезпечує енергозбереження та поліпшення якісних характеристики технологічних процесів і установок з регульованими електромеханічними системами. Бібл. 9, рис. 6.

Ключові слова: генератор, електродвигун, електричне гальмування, зовнішній, джерело, енергія, узгоджене, управління, генераиія.

\section{COORDINATED CONTROL OF MOTOR-GENERATOR VARIABLES IN THE ELECTRIC BREAKING MODE}

V. Teriaiev ${ }^{1}$, candidate of technical science, associate professor, S. Burian ${ }^{1}$, candidate of technical science, associate professor, V. Stiazhkin ${ }^{2}$, candidate of technical science, senior researcher

${ }^{1}$ National Technical University of Ukraine «Igor Sikorsky Kiev Polytechnic Institute», 03056, 37 Peremohy Av., Kyiv, Ukraine.

${ }^{2}$ Institute of Electrodynamics of the National Academy of Sciences of Ukraine, 03057, 56 Peremohy Av., Kyiv, Ukraine.

There are a number of installations and technological processes, the movement of which is carried out by an external source of energy, and the electric machine, not being the main source of movement, constantly or periodically is in the mode of electric generating braking to provide the desired characteristics of the workflow.

The problem solved in this research is to expand the functionality of the generator and the motor in the electric braking mode. The problem is solved by an automatic control of the coordinates of the electric machine in the generator mode. A feature of the proposed control method is that one or more coordinates of generator or motor in electric braking mode are forcibly set by an external energy source, and the goal of coordinated control of other variables of an electric machine is to provide a given law for converting mechanical energy into electrical or an algorithm for the movement of an executive object of a working machine.

The article presents example of the synthesis of regulated electric drive control algorithm based on the principle of coordinated control of variables.

The example concerns the inverted mode of operation of a pumping unit of a hydro storage power station. According to the criterion of constant output power under conditions of changing the liquid level, an algorithm for frequency control of an asynchronous machine is synthesized, which is realized by adjusting the calculated idling speed of the engine, the rotor of which rotates an external motion source with a speed, that can generally change according to an random law. The task of the control algorithm is to maintain a constant power generation energy, regardless of the actual speed of rotation of the rotor.

The proposed approach to the synthesis of generator mode of electric machines, through the use of the principle of coordinated control of variables, acquires qualitatively new properties, as compared with traditional methods of electric braking, increases the technical and economic indicators of the electromechanical system as a whole. Bibl. 9, fig. 6.

Keywords: generator, electric motor, electric braking, external, source, energy, coordinated, generation, control.

(C) B.I. Теряєв, С.О. Бур'ян, В.П. Стяжкін, 2020

Відновлювана енергетика. 2020. № 3 


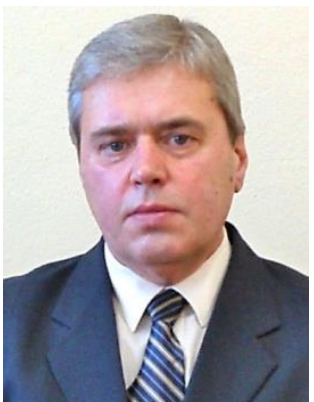

B.I. Теряєв

V. Teriaiev

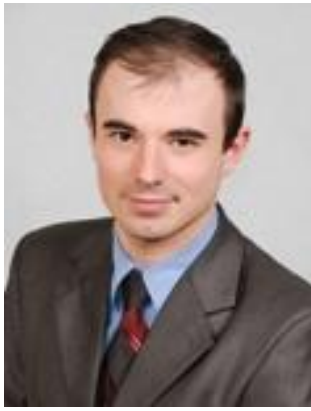

С.О. Бур'ян

S. Burian

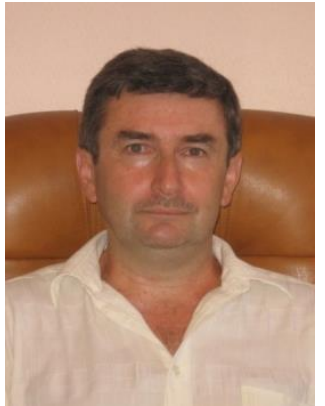

В.П. Стяжкін

V. Stiazhkin
Відомості про автора: доцент кафедри

Автоматизації електромеханічних систем та електроприводу Національного технічного університету України «Київський політехнічний інститут імені Ігоря

Сікорського», кандидат технічних наук.

Освіта: Національний технічний університет України «Київський політехнічний інститут», інженер-електромеханік за фахом «Електропривод і автоматизація промислових установок».

Наукова сфера: Системи магнітного підвішування та лінійного електроприводу; взаємозв'язані багатоканальні слідкуючі електромеханічні системи.

Публікації: 122, 15 патентів.

ORCID: 0000-0002-8634-0895

Контакти: +38 (044) 204-83-56

e-mail: kpivit@gmail.com

Відомості про автора: доцент кафедри Автоматизації електромеханічних систем та електроприводу Національного технічного університету України «Київський політехнічний інститут імені Ігоря Сікорського», кандидат технічних наук. Освіта: Національний технічний університет України «Київський політехнічний інститут», магістр електромеханіки за спеціальністю «Електромеханічні системи автоматизації та електропривод».

Наукова сфера: енергоефективні електромеханічні системи автоматизації турбомеханізмів.

Публікації: 128, 1 патент.

ORCID: 0000-0002-4947-0201

Контакти: +38-050-840-31-55

e-mail: sburyan18@gmail.com

Відомості про автора: старший науковий співробітник відділу перетворення та стабілізації електромагнітних процесів Інституту електродинаміки НАН України, кандидат технічних наук.

Освіта: Національний технічний університет України «Київський політехнічний інститут», інженер-електрик за фахом «Електропривод і автоматизація промислових установок».

Наукова сфера: напівпровідникові перетворювачі напруги та струму, частотні лінійні електроприводи, автоматизовані гібридні системи регулювання з нечіткою логікою.

Публікації: 72, 11 патентів.

ORCID: 0000-0003-0602-1112

Контакти: +38 (044) 456-42-48

e-mail: tems@ukr.net
Author information: Associate Professor of the Department of Automation of Electromechanical Systems and Electric Drive of the National Technical University of Ukraine "Igor Sikorsky Kyiv Polytechnic Institute" (Igor Sikorsky KPI), $\mathrm{PhD}$ of Technical sciences.

Education: National Technical University of Ukraine "Kiev Polytechnic Institute", engineerelectromechanic in the specialty "Electric drive and automation of industrial plants".

Research area: Magnetic levitation systems and linear electric drives; interconnected and multichannel tracking electromechanical systems.

Publications: 122,15 patents.

ORCID: 0000-0002-8634-0895

Contacts: +38 (044) 204-83-56

e-mail: kpivit@gmail.com

Author information: Associate Professor of the Department of Automation of Electromechanical Systems and Electric Drive of the National Technical University of Ukraine "Igor Sikorsky Kyiv Polytechnic Institute" (Igor Sikorsky KPI), $\mathrm{PhD}$ of Technical sciences.

Education: National Technical University of Ukraine "Kyiv Polytechnic Institute", Master of Electrical Engineering for the specialty

"Electromechanical Automation Systems of the Electric Drive".

Research area: energy-efficient electrical automation systems of turbomechanisms.

Publications: 128,1 patent

ORCID: 0000-0002-4947-0201

Contacts: +38-050-840-31-55

e-mail: sburyan18@gmail.com

Information about the author: Senior Researcher, Department of Transformation and Stabilization of Electromagnetic Processes of Institute of Electrodynamics of the National Academy of Sciences of Ukraine, PhD of Technical sciences.

Education: National Technical University of Ukraine "Kyiv Polytechnic Institute", engineerelectric in the specialty "Electric drive and automation of industrial plants".

Research area: semiconductor converters of voltage and current, frequency linear electric drives, automated hybrid control systems with fuzzy logic.

Publications: 72, 11 patents.

ORCID: 0000-0003-0602-1112

Contacts: +38 (044) 456-42-48

e-mail: tems@ukr.net
Вступ. Існує ряд установок та технологічних процесів, рух в яких здійснюється за рахунок зовнішнього джерела енергії, а електрична машина, не будучи основним джерелом руху, постійно або періодично знаходиться в режимі генераторного електричного гальмування для забезпечення потрібних характеристики робочого процесу. Такі режими руху характерні для турбін вітрогенераторів, насосів та вентиляторів в оберненому режимі роботи [1-5], підйомнотранспортним машинам в режимі опускання 
вантажу, механізмам неперервних прокатних станів, поєднані рухомою смугою, рухомому складу транспортних засобів в процесі гальмування та іншім.

Існуючі підходи до керування режимами генерації або генераторного гальмування електричних машин, як правило, мають обмежене використання і вузьке спрямування на конкретні схемотехнічні рішення для окремих видів електричних машин, перетворювальних пристроїв та механізмів [6-7]. Їх недоліком $є$ також відсутність керованості процесом перетворення електричної енергії в режимах генераторного гальмування в широких межах.

Мета та завдання дослідження. Задачею даного дослідження $€$ розширення функціональних можливостей генератора та двигуна в режимі електричного гальмування на основі застосування узагальнених підходів до синтезу алгоритмів керування енергетичними установками 3 використанням запропонованого принципу узгодженого регулювання координат [8], який полягає в тому, що одна або декілька координат електричної машини задаються зовнішнім джерелом руху, а регулюванням інших координат забезпечується здійснення керованого режиму генерації енергії.

Матеріали досліджень. У багатьох галузях промисловості, комунального господарства, транспорту, гідроенергетики відбувається накопичення значної кількості рідини у резервуарах. В якості прикладів можна навести водонапірні башти, ємності пивзаводів, нафтосховища, шлюзи, танкери, приливні та гідроакумулюючі електростанції (ГАЕС). Загальною рисою вказаних гідроустановок $\epsilon$ перетворення електричної енергії, яка споживається насосною установкою під час нагнітання рідини у резервуар в потенціальну енергію рідини, яка визначається рівнем іï підйому. Як правило, в процесі зворотного витіканні рідини з резервуарів накопичена енергія витрачається безповоротно у вигляді втрат. І лише в ГАЕС передбачається повернення потенціальної енергії водяної маси в електричну енергію шляхом подачі накопиченої води безпосередньо на гідротурбіни, або за допомогою насосів оберненої дії. Розглянемо роботу оборотного насосного гідроелектроагрегату (ГЕА) більш докладно.

В крупних енергосистемах велику частку складають потужності теплових i атомних електростанцій, які не можуть швидко змінювати вироблення електроенергії при денних і нічних коливаннях енергоспоживання або ж роблять це 3 великими втратами. Це призводить до встановлення істотно більшої комерційної вартості пікової електроенергії в енергосистемі у порівнянні з вартістю електроенергії, виробленої в нічний період. В таких умовах залучення ГАЕС економічно вигідно i підвищує ефективність використання інших потужностей, а також надійність енергопостачання.

В роботі ГАЕС застосовується комплекс генераторів і насосів, або оборотні ГЕА, які здатні працювати як в режимі генераторів, так і в режимі насосів. Під час нічного провалу енергоспоживання ГАЕС отримує з енергомережі дешеву електроенергію і витрачає ii на закачку води в верхній б’єф (насосний режим). Під час ранкового та вечірнього піків енергоспоживання ГАЕС скидає воду 3 верхнього б'єфу в нижній, виробляє при цьому дорогу пікову електроенергію, яку віддає в енергомережу (генераторний режим).

Досвід використання ГАЕС 3 метою регулювання електричних режимів показав, що вони $є$ не тільки генеруючим джерелом, а й джерелом надання системних послуг, що сприяють як оптимізації добового графіка навантажень, так і підвищенню надійності і якості електропостачання.

В якості оборотних гідротурбін використовується спеціальний тип радіальноосьових гідротурбін, які можуть працювати як в турбінному, так i в насосному режимах, зберігаючи при цьому високий ККД. Дана особливість досягається за допомогою лопатей, що мають спеціальну форму. Потужність таких турбін досягає 400 МВт. Робочі характеристики: напір від 40 м до 550 м; діаметр робочого колеса від 1 м до 7,5 м; особливості конструкції - робота в турбінному, насосному i компенсуючому (як синхронний компенсатор) режимах.

В той же час відомі технічні рішення передбачають в турбінному режимі переведення приводного електродвигуна ГЕУ у некерований процес рекуперативного гальмування 3 поверненням накопиченої потенціальної енергії рідини в електричну мережу за рахунок обертання турбіни насосу зі швидкістю, вище швидкості холостого ходу електродвигуна, який при цьому переходить у генераторний режим. При використанні в якості двигуна-генератора асинхронної машини режим рекуперативного гальмування 3 поверненням енергії в мережу відбувається за рахунок зміни фази струму статора 3 поверненням активної потужності у мережу. Реактивна потужність при цьому продовжує споживатись 3 мережі. При застосуванні синхронної машини в турбінному 
режимі ГЕА здійснюється генерування енергії в мережу та компенсація реактивної потужності.

В статті наведено практичний приклад синтезу алгоритму керування для оберненого режиму роботи асинхронного електроприводу насосної установки ГАЕС на основі запропонованого принципу узгодженого регулювання координат [8]. За критерієм незмінності потужності генерування в умовах зміни рівня рідини в резервуарі синтезовано алгоритм частотного керування, який реалізовано шляхом регулювання розрахункової швидкості холостого ходу асинхронної машини, ротор якої обертається зовнішнім джерелом руху зі швидкістю, що в загальному випадку може змінюватись за довільним законом. Завданням алгоритму керування $€$ підтримання постійної потужності генерації енергії в широких межах зміни швидкості обертання ротора, яка залежить від рівня рідини в резервуарі.
Кероване перетворення накопиченої потенціальної енергії рідини в електричну енергію здійснюється оборотним ГЕА 3 використанням асинхронного частотнорегульованого електроприводу. В загальному випадку ГЕА складається 3 резервуару 1, трубопроводу 2, оборотного насосу 3, асинхронного двигуна-генератора 3 короткозамкненим ротором $G$, перетворювача частоти $U Z$, підключеного до мережі $M$, датчика кутової швидкості ротора $B R$ та керуючого пристрою КП (див. рис. 1). На рисунку позначені: $U_{M}$ - напруга мережі живлення; $U_{3 \Pi}-$ завдання потужності; $U_{3}-$ завдання частоти; $f$ - регульована частота напруги на виході перетворювача. Задачею КП є управління перетворювальним та електродвигунним пристроями 3 метою забезпечення заданого алгоритму роботи оборотного двигуна-генератора.

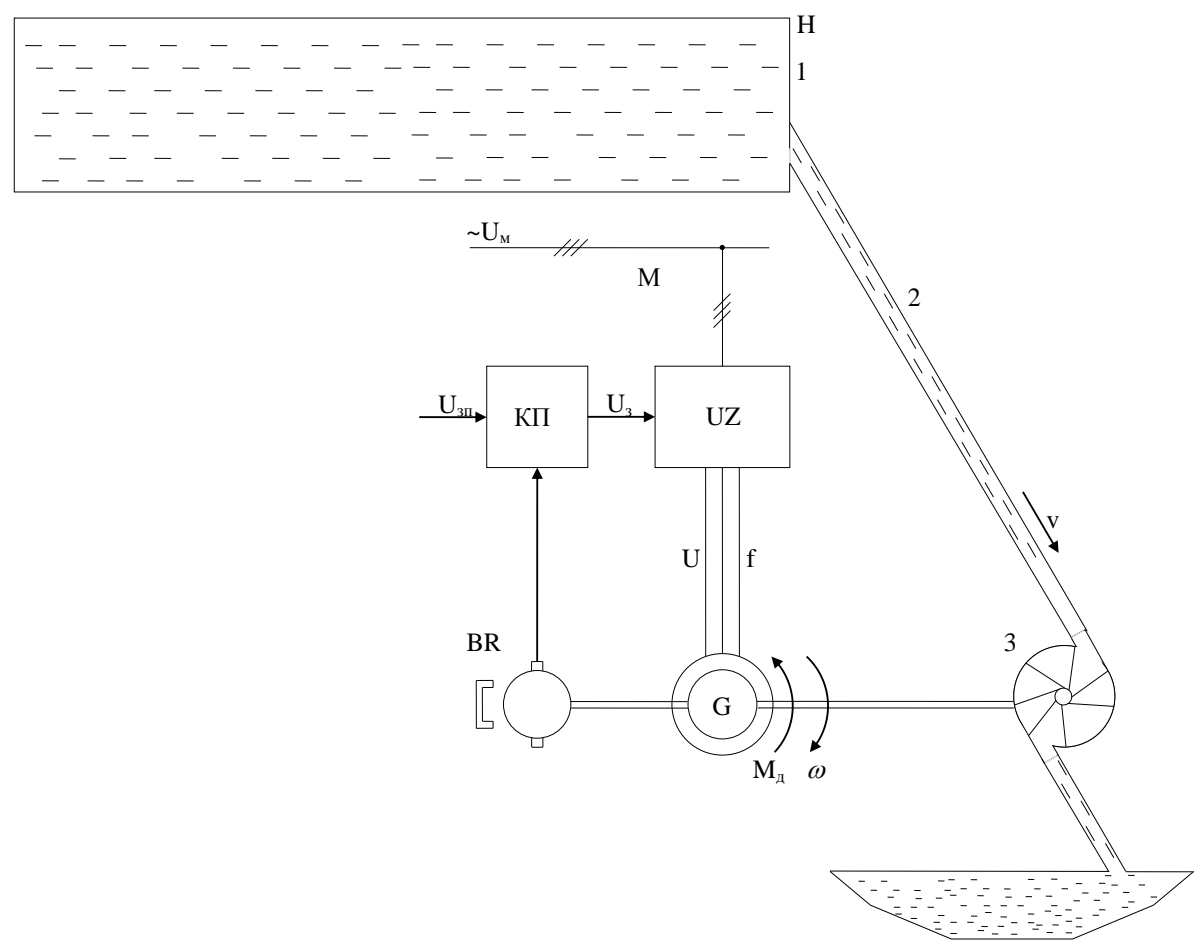

Рис. 1. Функціональна схема оборотного ГЕА.

Fig. 1. Functional scheme of the reverse GEA.

Для розробки алгоритму керування насосною установкою в режимі генерації енергії 3 постійною потужністю скористаємось рівнянням лінеаризованої механічної характеристики асинхронної машини (1) та спрощеною моделлю асинхронного частотно-керованого електроприводу [9]:

$$
\left(\omega_{0}-\omega\right) \cdot \beta=M_{\text {д }}=\frac{P_{3}}{\omega},
$$

де $\omega$ - швидкість ротору асинхронної машині; $\omega_{0}$ - розрахункова швидкість холостого ходу; $\beta$ коефіцієнт жорсткості механічної характеристики; $M_{\text {Д }}-$ момент двигуна в генераторному режимі; $P_{3}$ - задана потужність генерації в рекуперативному режимі. В гальмівному режимі момент двигуна та потужність мають від'ємні знаки.

При синтезі алгоритму керування приймаємо, що швидкість ротора насосу в 
турбінному режимі прямо пропорційно залежить від швидкості $v$ рідини в трубопроводі.

Розв'язуючи рівняння (1) відносно $\omega_{0}$, отримуємо залежність, яка визначає закон керування швидкістю холостого ходу асинхронної машини i забезпечує незмінною задану величину активної потужності, що повертається в мережу живлення, в умовах зміни рівня i, відповідно, напору та швидкості рідини, що витікає з резервуару:

$$
\omega_{0}=\frac{P_{3}}{\beta \omega}+\omega,
$$

Як видно 3 (2), для реалізацій даної залежності необхідна лише одна вимірювана змінна - сигнал датчика швидкості ротора асинхронної машини.

Структурна схема функціонального блоку, який реалізує алгоритм керування (2), представлена на рис. 2. На рисунку позначені: $k_{\text {д, }}$ $T_{E}$ - коефіцієнт передачі та електромагнітна стала часу асинхронного електродвигуна; $k$ масштабуючий коефіцієнт.

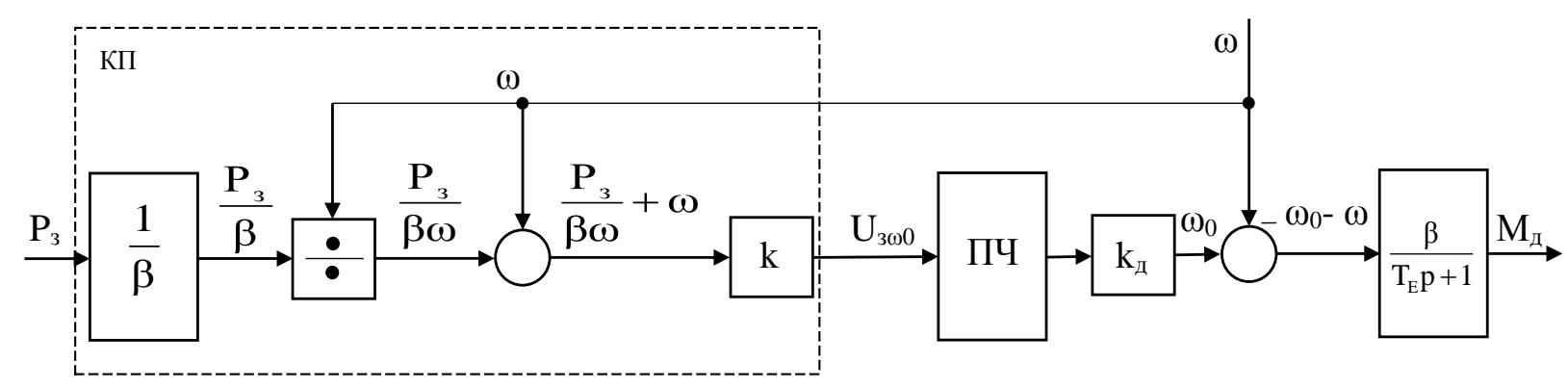

Рис. 2. Структурна схема системи автоматичного керування потужності в режимі рекуперації.

Fig. 2. Structural diagram of a system of automatic control in the generator mode.

Робота алгоритму керування ілюструється механічними характеристиками електроприводу, представленими на рис. 3. Для підтримання сталого режиму рекуперативного гальмування розрахункова швидкість холостого ходу асинхронної машини повинна автоматично знижуватись відповідно до зниження швидкості витікаючої рідини, внаслідок зменшення іiі рівня в резервуарі; при цьому різниця швидкостей холостого ходу i ротору машини визначає величину гальмівного моменту на валу двигуна, виходячи $з$ умови $P_{3}=$ const.

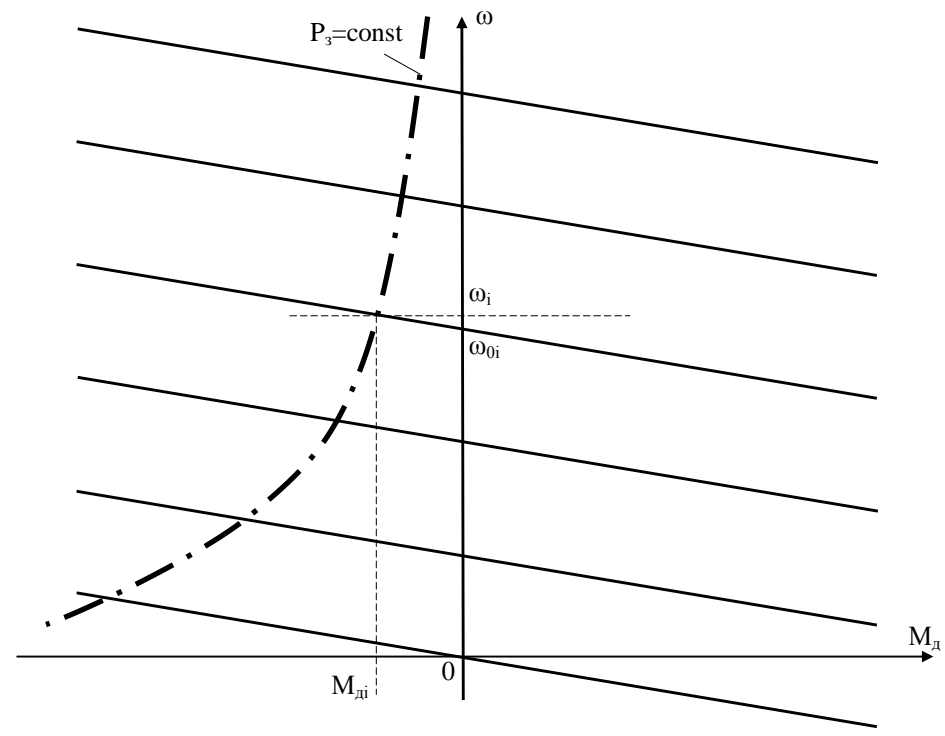

Рис. 3. Механічні характеристики асинхронного електродвигуна в режимі рекуперативного гальмування при стабілізації потужності генерації.

Fig. 3. Mechanical characteristics of an asynchronous electric motor in recuperation mode with stable power generation. 
Для підтвердження працездатності розробленого алгоритму керування оберненим ГЕА було проведено моделювання генераторного режиму роботи асинхронного частотнорегульованого електроприводу для процесу вільного витікання рідини з резервуару. В процесі моделювання вважалося, що швидкість рідини в трубопроводі в турбінному режимі зворотно пропорційно залежить від часу. Останнє випливає 3 формули, яка описує процес вільного витоку рідини з резервуару при змінному напорі:

$$
t=\frac{2 S H}{\mu S_{0} \sqrt{2 g H}}=\frac{2 S H}{\mu S_{0} v}
$$

де $v=\sqrt{2 g H} \quad-$ швидкість рідини в трубопроводі, м/с; $H$ - висота рівня рідини над отвором (напір), м; $g$ - гравітаційна стала, м/ $\mathrm{c}^{2} ; S$ - площа поверхні резервуару, ${ }^{2} ; S_{0}$ - площа отвору трубопроводу, $\mathrm{m}^{2} ; \mu$ - коефіцієнт витрати.

Результати моделювання представлені на рис. 4.

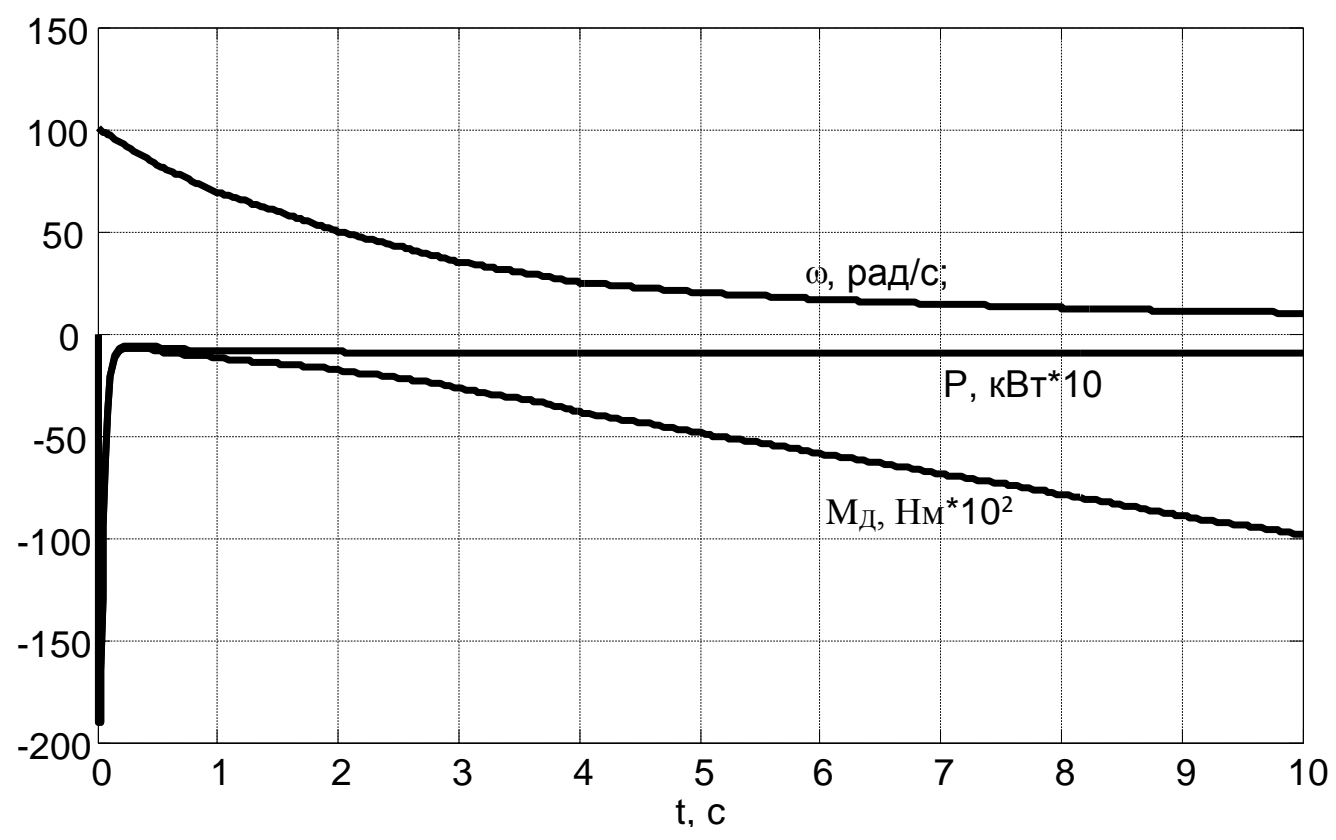

Рис. 4. Перехідний процес рекуперативного гальмування зі стабілізацією потужності генерації.

Fig. 4. The process of recuperation with stable power generation.

3 метою перевірки працездатності синтезованого алгоритму узгодженого керування були проведені дослідження меж його використання на основі повної моделі асинхронної машини в діапазоні активної потужності від 20 кВт до 100 кВт.

На рисунку 5 представлено результати моделювання роботи генератора 3 частотним керуванням швидкості за законом $U / f=$ const при використанні алгоритму стабілізації активної потужності в режимі рекуперації. Перевірка алгоритму здійснена шляхом формування завдання швидкості холостого ходу двигуна за синусоїдальним законом. На рисунку 6 наведено відповідний графік вихідної активної потужності при завданні 50 кВт.

3 результатів моделювання видно, що алгоритм виконує поставлене завдання стабілізації потужності рекуперативного гальмування навіть на малих швидкостях. 

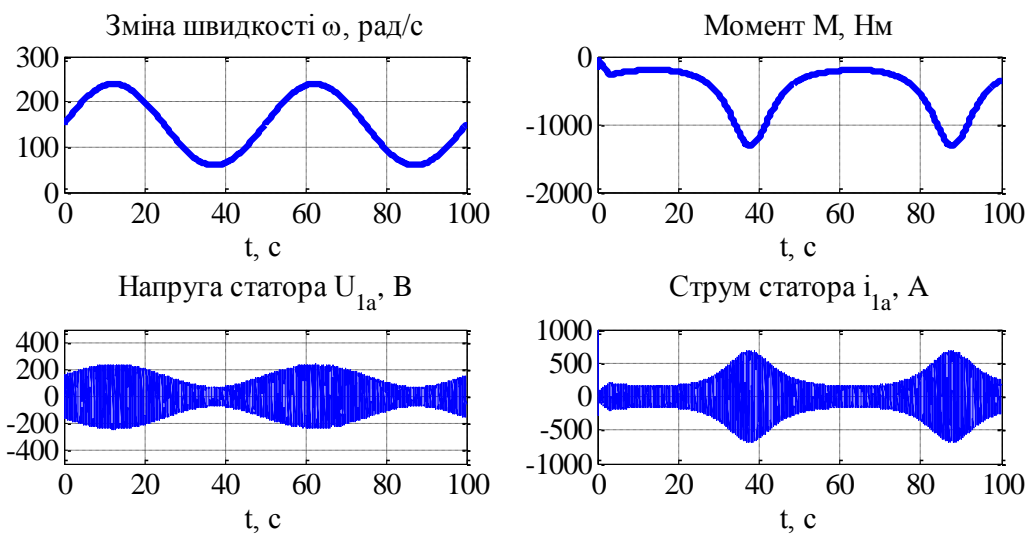

Потокозчеплення ротора $\psi_{2 \mathrm{a}}$, Вб
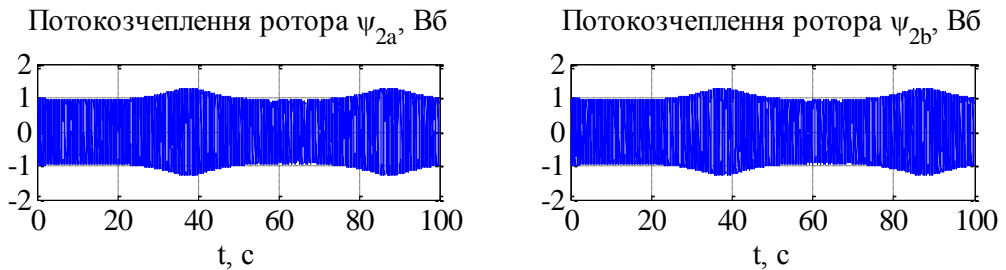

Рис. 5. Результати моделювання роботи генератора з використанням алгоритму узгодженого керування та закону U/f = const (на основі повної моделі).

Fig. 5. The results of modeling the generator using the algorithm of coordinated control and the law $U / f=$ const $($ based on the complete model).

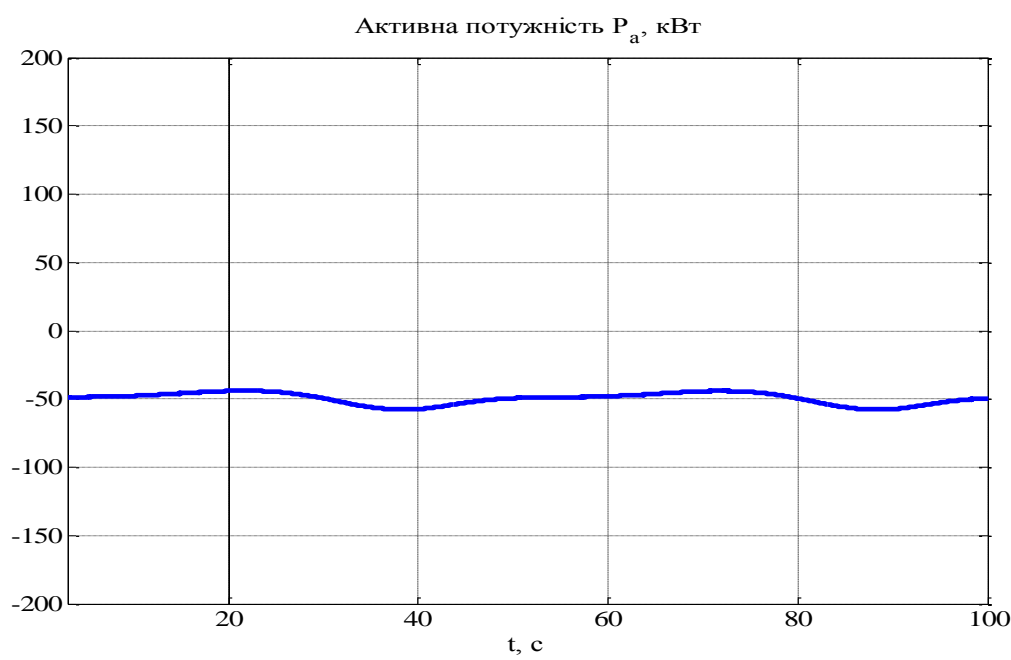

Рис. 6. Активна потужність на виході генератора.

Fig. 6. Active power at the generator output.

Як видно 3 синтезованого алгоритму та результатів моделювання частотне керування асинхронною машиною в режимі генераторного гальмування при зниженні рівня рідини внаслідок витікання 3 резервуару забезпечує стабілізацію потужності у квазістатичному генераторному режимі в достатньо широких межах. Це підтверджує можливість здійснення узгодженого регулювання координат двигуна-генератора 3 метою стабілізації активної потужності, яка повертається в мережу, за потрібним законом.

\section{Висновки.}

1. Обгрунтовано новий принцип узгодженого регулювання координат генераторів та двигунів в режимі електричного гальмування для установок оберненої дії, де одна або декілька координат задаються зовнішнім джерелом енергії, а регулюванням інших координат забезпечується заданий закон перетворення механічної енергії в електричну або алгоритм руху робочої машини.

2. Використання принципу узгодженого регулювання координат забезпечує керований процес перетворення механічної енергії в електричну від джерел енергії та руху різноманітної фізичної природи.

3. Показана доцільність створення оборотних ГЕА, які дозволяють здійснювати керований процес перетворення накопиченої потенціальної енергії рідини в електричну енергію. 
4. Наведено приклад практичної реалізації алгоритму керування насосною установкою в оберненому режимі роботи за критерієм незмінності потужності генерування, що свідчить про можливість і доцільність використання запропонованого підходу.

5. Запропоновано методологію синтезу алгоритмів керування енергетичними, промисловими та транспортними установками, які забезпечують покращення технікоекономічних показників процесу перетворення механічної енергії в електричну.

6. Поєднання функцій генератора i електродвигуна в єдиному функціональному комплексі допомагає вирішувати проблеми енергозбереження i покращення технікоекономічних характеристик процесів і установок 3 регульованими електромеханічними системами.

1. Pumped-storage hydroelectric power stations in China. December 2012. [Електронний ресурc]. URL:http://www.indus tcards.com/ps-china.htm. (дата звернення: 25.01.2020).

2. General Electric Renewable Energy. [Електронний pecypc]. URL: https://www.ge.com/renewableenergy/hydropower/hydro-pumped-storage . (дата звернення: 25.01.2020).

3. Ela E., Krad I., Kirby B., Botterud A., Milostan C., Koritarov $V$. The Role of Pumped Storage Hydro Resources in Electricity Markets and System Operation. Preprint. National Renewable Energy Laboratory and Argonne National Laboratory. HydroVision International, Denver. Colorado. 23-26 July. 2013. 12 p. [Електронний ресурc]. URL: https://www.nrel.gov/docs/f y13osti/58655.pdf. (дата звернення: 25.01.2020).

4. Rehman Sh., Al-Hadhrami L.M., Alam Md.M. Pumped hydro energy storage system: A technological review. Renewable and Sustainable Energy Reviews. Vol. 44. 2015. Pp. 586-598.

5. Levine J.G. Pumped Hydroelectric Energy Storage and Spatial Diversity of Wind Resources as Methods of Improving Utilization of Renewable Energy. B.S. Michigan Technological University. 2003. 100 p. [Електронний ресурс]. URL: http://www.colorado.edu/engineering/energystorage/files/MSTh esis_JGLevine_final.pdf (дата звернення: 25.01.2020).

6. King D.J., Bradley D.A., Mansoor S.P., Jones D.I., Aris F.C., Jones G.R. Advanced Control Strategies For Pumped Storage Plant. Conference. Hydrovision 2020. Portland. USA. August.2020. 11 p. [Електронний pecypc]. URL: https://www.r esearchgate.net/publication/304173455_Advanced_Control_Stra tegies_for_Pumped_Storage_Plant/link/576914c908ae3bf53d32f 27f/download. (дата звернення: 25.01.2020).

7. Technical Analysis of Pumped Storage and Integration with Wind Power in the Pacific Northwest. Final Report. prepared for U.S. Army. Corps of Engineers Northwest Division Hydroelectric Design Center prepared by: August 2009. 166 p. [Електронний pecypc]. URL: https://www.hydro.org/wpcontent/uploads/2017/08/PS-Wind-Integration-Final-Reportwithout-Exhibits-MWH-3.pdf. (дата звернення: 25.01.2020).

8. Спосіб регулювання координат генератора та двигуна в режимі електричного гальмування: пат. 126104 Україна. № u201712078. Заявл. 08.12.2017. Опубл. 11.06.2017. Бюл. № 11.
9. Попович М.Г., Теряєв В.І., Кіселичник О.І., Бур'ян C.O. Особливості синтезу та дослідження електромеханічних систем з послідовною корекцією та частотно регульованими асинхронними двигунами. Вісник Кременчуцького державного політехнічного університету. Кременчук. КДПУ. 2007. Вип. 3/2007 (44). Частина 2. С. 12-16.

\section{RFERENCES}

1. Pumped-storage hydroelectric power stations in China. December 2012. [Electronic resource]. URL: http://www.indust cards.com/ps-china.htm. (Applying date: 25.01.2020). [in English].

2. General Electric Renewable Energy. [Electronic resource]. URL: https://www.ge.com/renewableenergy/hydropower/hydro-pumped-storage . (Applying date:25.01.2020). [in English].

3. Ela E., Krad I., Kirby B., Botterud A., Milostan C., Koritarov $V$. The Role of Pumped Storage Hydro Resources in Electricity Markets and System Operation. Preprint. National Renewable Energy Laboratory and Argonne National Laboratory. HydroVision International, Denver. Colorado. 23-26 July. 2013. 12 p. [Electronic resource]. URL: https://www.nrel.gov/docs/fy1 3osti/58655.pdf. (Applying date:25.01.2020). [in English].

4. Rehman Sh., Al-Hadhrami L.M., Alam Md.M. Pumped hydro energy storage system: A technological review. Renewable and Sustainable Energy Reviews. Vol. 44. 2015. Pp. 586-598. [in English].

5. Levine J.G. Pumped Hydroelectric Energy Storage and Spatial Diversity of Wind Resources as Methods of Improving Utilization of Renewable Energy. B.S. Michigan Technological University. 2003. 100 p. [Electronic resource]. URL: http://www .colorado.edu/engineering/energystorage/files/MSThesis_JGLevi ne_final.pdf (Applying date: 25.01.2020). [in English].

6. King D.J., Bradley D.A., Mansoor S.P., Jones D.I., Aris F.C., Jones G.R. Advanced Control Strategies For Pumped Storage Plant. Conference. Hydrovision 2020. Portland. USA. August. 2020. 11 p. [Electronic resource]. URL: https://www.res earchgate.net/publication/304173455_Advanced_Control_Strate gies_for_Pumped_Storage_Plant/link/576914c908ae3bf53d32f2 7f/download. (Applying date: 25.01.2020). [in English].

7. Technical Analysis of Pumped Storage and Integration with Wind Power in the Pacific Northwest. Final Report. prepared for U.S. Army. Corps of Engineers Northwest Division Hydroelectric Design Center prepared by: August 2009. 166 p. [Electronic resource]. URL: https://www.hydro.org/wpcontent/uploads/2017/08/PS-Wind-Integration-Final-Reportwithout-Exhibits-MWH-3.pdf. (Applying date:25.01.2020). [in English].

8. Sposib rehuliuvannia koordynat heneratora ta dvyhuna $\mathrm{v}$ rezhymi elektrychnoho halmuvannia. [The method of coordinates the generator and the motor control in electric braking mode]. pat. 126104 Ukraina. № u201712078. Zaiavl. 08.12.2017. Opubl. 11.06.2017. Biul. № 11. [in Ukrainian].

9. Popovich M.G., Teriaiev V.I., Kiselychnyk O.I., Burian S.O. Osoblyvosti syntezu ta doslidzhennia elektromekhanichnykh system z poslidovnoiu korektsiieiu ta chastotnorehulovanymy asynkhronnymy dvyhunamy. [Features of synthesis and access of electrical systems with a last-minute correction and frequencycontrolled asynchronous motors]. Visnyk Kremenchutskoho derzhavnoho politekhnichnoho universytetu. Kremenchuk. KDPU. 2007. Vyp. 3/2007 (44). Vol. 2. Pp. 12-16. [in Ukrainian]. 